\title{
Frameshift and Splice-Junction Mutations in the Sterol 27-Hydroxylase Gene Cause Cerebrotendinous Xanthomatosis in Jews of Moroccan Origin
}

\author{
Eran Leitersdorf, Ayeleth Reshef, Vardiella Meiner, Rubina Levitzki, Sigal Pressman Schwartz, Eldad J. Dann, \\ Neville Berkman, James J. Cali, ${ }^{*}$ Laurent Klapholz, * and Vladimir M. Berginer \\ Department of Medicine and Lipid Research Laboratory, and *Department of Dermatology, Hadassah University Hospital, \\ 91120 Jerusalem, Israel; ${ }^{\ddagger}$ Department of Molecular Genetics, University of Texas Southwestern Medical Center, \\ Dallas, Texas 75235; and ${ }^{\S}$ Department of Neurology, Soroka Medical Center, Faculty of Health Sciences, \\ Ben-Gurion University of the Negev, 84101 Beer-Sheba, Israel
}

\begin{abstract}
The sterol 27-hydroxylase (EC 1.14.13.15) catalyzes steps in the oxidation of sterol intermediates that form bile acids. Mutations in this gene give rise to the autosomal recessive disease cerebrotendinous xanthomatosis (CTX). CTX is characterized by tendon xanthomas, cataracts, a multitude of neurological manifestations, and premature atherosclerosis. A relatively high prevalence of the disease has been noted in Jews originating from Morocco. The major objectives of the present investigation were to determine the gene structure and characterize the common mutant alleles that cause CTX in Moroccan Jews. The gene contains nine exons and eight introns and encompasses at least $18.6 \mathrm{~kb}$ of DNA. The putative promoter region is rich in guanidine and cytosine residues and contains potential binding sites for the transcription factor Sp1 and the liver transcription factor, LF-B1. Blotting analysis revealed that the mutant alleles do not produce any detectable sterol 27 -hydroxylase mRNA. No major gene rearrangements were found and single-strand conformational polymorphism followed by sequence analysis identified two underlying mutations: deletion of thymidine in exon 4 and a guanosine to adenosine substitution at the 3 ' splice acceptor site of intron 4 of the gene. The molecular characterization of CTX in Jews of Moroccan origin provides a definitive diagnosis of this treatable disease. (J. Clin. Invest. 1993. 91:2488-2496.) Key words: atherosclerosis • bile salts • cholesterol metabolism • cytochrome P450 • dementia
\end{abstract}

\section{Introduction}

Cerebrotendinous xanthomatosis (CTX) ${ }^{1}$ is a rare, autosomal recessive lipid-storage disease. The clinical hallmarks of the disease are tendon xanthomas, juvenile cataracts, and progressive neurological dysfunction (1). The latter includes behavioral abnormalities; dementia; pyramidal paresis; cerebellar,

Dr. James J. Cali's present address is Weis Center for Research, Geisinger Clinic, Danville, PA 17822-2601.

Address reprint requests to Dr. Eran Leitersdorf, Lipid Research Laboratory, Department of Medicine, Hadassah University Hospital, 91120 Jerusalem, Israel.

Received for publication 20 October 1992 and in revised form 23 December 1992.

1. Abbreviations used in this paper: CTX, cerebrotendinous xanthomatosis; SSCP, single-strand conformational polymorphism.

J. Clin. Invest.

(C) The American Society for Clinical Investigation, Inc. 0021-9738/93/06/2488/09 \$2.00

Volume 91, June 1993, 2488-2496 brain-stem, spinal, and peripheral nerve disorder; and epileptic seizures (2). In addition, osteoporosis with frequent bone fractures ( 3 ) and premature atherosclerosis (4) have recently been documented. Cholestanol, the $5 \alpha$-dihydro derivative of cholesterol, is found in all tissues, particularly in the Achilles tendons, brain, and lungs $(5,6)$. The clinical diagnostic criteria include the demonstration of increased concentrations of bile alcohols in the serum and urine with low to normal plasma cholesterol concentrations (7). If untreated, CTX is a slowly progressive lethal disease (5). Early diagnosis of CTX is crucial inasmuch as long-term treatment with chenodeoxycholic acid (8) with or without an hydroxymethylglutaryl coenzyme A reductase inhibitor (9) may prevent the neurological complications of the disease.

Based on intermediary metabolism studies, Salen and coworkers (10) postulated in 1979 that a defect in a microsomal sterol 24S-hydroxylase causes CTX. In 1980, Oftebro et al. (11) reported that a defect in the mitochondrial sterol 26-hydroxylase (currently designated 27-hydroxylase) is the cause of CTX. These authors could detect no sterol 26-hydroxylase activity in a liver biopsy from a Norwegian CTX subject. Several subsequent studies employing fibroblasts from different CTX patients have confirmed a lack of mitochondrial 26-hydroxylase activity in this disease (12).

The sterol 27-hydroxylase (EC 1.14.13.15) is a mitochondrial enzyme catalyzing the initial steps in the oxidation of the side chain of sterol intermediates in the pathway for metabolism and excretion of cholesterol in mammals. The enzymatic hydroxylation of $5 \beta$-cholestane- $3 \alpha, 7 \alpha, 12 \alpha$-triol at C-27 occurs in mitochondria and is catalyzed by an enzyme complex comprising sterol 27-hydroxylase, ferredoxin, and NADPH-ferredoxin reductase (13). The sterol 27-hydroxylase was purified and characterized as mitochondrial member of the cytochrome P450 family $(14,15)$. This enzyme hydroxylates a spectrum of sterol substrates as well as vitamin $D_{3}(14,16)$. In agreement with this finding, abnormal vitamin $\mathrm{D}$ metabolism has been recently observed in CTX patients (3).

Molecular cloning of the human sterol 27-hydroxylase cDNA has shown that the protein consists of a 498-amino acid mature enzyme and a 33-amino acid mitochondrial signal sequence (17). RNA blotting experiments demonstrated mRNAs of $\sim 1.8-2.2 \mathrm{~kb}$ in liver and fibroblast cells. The gene encoding human sterol 27-hydroxylase (CYP27) has been mapped to the distal portion (q33-qter) of the long arm of chromosome 2(18). After the molecular cloning of the human sterol 27-hydroxylase complementary DNA, two missense mutations were characterized in CTX cases (18). Identification of mutations that result in absence of any detectable mRNA required the characterization of the sterol 27-hydroxylase gene structure, a major goal of the current investigation. 
Although rare in most populations, an interesting and experimentally approachable instance of abnormally high frequency of CTX has been reported in Israel (19). This finding mandates introduction of direct detection methods to diagnose the heterozygote state. The molecular characterization of mutations causing CTX in Moroccan Jews was an additional objective of the present study.

\section{Methods}

Determination of the sterol 27-hydroxylase gene structure Genomic cloning. A human lymphocyte genomic library (in Lambda Dash) was obtained from Stratagene, Inc. (La Jolla, CA) and screened with ${ }^{32} \mathrm{P}$-labeled oligonucleotides complementary to cDNA sequences of the human sterol 27-hydroxylase cDNA. One clone (HG27-4) hybridized with oligonucleotide JC21 5'-TCCGGCGGCGGCAACGGAGCTTAGA-3' derived from 5 ' sequences of the cDNA. Three clones (HG27-1,2,3) hybridized with oligonucleotides JC25 5'-AAGCAGCGCTCTATACGGATGCTTT-3' and JC33 5'-TGGTCCCCACAAACTCCCGGATCATA-3' derived from other coding sequences including the 3 ' region of the cDNA. An EcoRI fragment of clone HG271 was subcloned into a pBS vector (Stratagene, Inc.) and designated p27OHGE. The BamHI-SphI fragment of p27OHGE was subcloned into bacteriophage M13 mp18, mp19 vectors (New England Biolabs, Beverly, MA ) and designated 27OHBS. A SacI fragment from HG27-4 was subcloned into a pBS vector and designated p27OHGS. The SacISmaI fragment of this plasmid and a PstI fragment of HG27-4 were subcloned into bacteriophage M13 and were designated 27OHSS and 27OHPS, respectively (Fig. $1 A$ ).

$P C R$ amplification. We used PCR amplification (20) to verify the size of introns 2 and 5. Oligonucleotides were devised according to the cDNA sequence (17). PCR-oligonucleotide JC52 (nucleotides 428448) (5'-ACCGGGACCAGCACGACCTGA-3') and JC24 (nucleo- tides 585-560) (5'-TCGAGTCATAAAGTCATCAATCACCT-3') were used for the amplification of intron 2. Oligonucleotides RL7 ( nucleotides 1012-1031) (5'-GAGCTGCTCATGGCTGGAGT-3') and RL8 (nucleotides 1092-1073) (5'-GATCTCAGGGTCCTTTGAGA$\left.3^{\prime}\right)$ were used to amplify intron 5 of the gene. Plasmid DNA (p27OHGE) was used as a DNA template. The PCR protocol included 1 min of denaturation at $95^{\circ} \mathrm{C}$ and $5 \mathrm{~min}$ of annealing and extension at $68^{\circ} \mathrm{C}$ using Thermus aquaticus DNA polymerase enzyme (Perkin Elmer Cetus, Norwalk, CT) for 35 cycles. After DNA amplification, products were size fractionated on a $6 \%$ polyacrylamide gel and subjected to ethidium staining. Band sizes were determined according to $\Phi \mathrm{X}$-HaeIII size standards.

DNA sequence analysis. DNA sequence analysis was performed using a Sequenase kit (United States Biochemicals, La Jolla, CA) either on single-stranded DNA templates (bacteriophage M13 clones) or on double-stranded plasmid DNA (p27OHGE) using oligonucleotide primers derived from the sterol 27-hydroxylase cDNA sequence.

Southern blotting analysis of genomic DNA. High molecular weight human genomic DNA was prepared from peripheral blood leukocytes as described (21). The DNA was quantified and diluted to a final concentration of $0.1 \mathrm{mg} / \mathrm{ml} .8 \mu \mathrm{g}$ of genomic DNA were digested with each restriction endonuclease using the buffer suggested by the manufacturer. Subsequently, the DNA was subjected to electrophoresis on a $0.8 \%(\mathrm{wt} / \mathrm{vol})$ agarose and transferred to a nylon membrane (Biotrans, ICN Biomedicals, Irvine, CA ). A single-stranded $\left[\alpha-{ }^{32} \mathrm{P}\right] \mathrm{dCTP}$-labeled probe derived from the human sterol 27-hydroxylase cDNA (exons 3-8) was prepared by the method of Church and Gilbert (22). Hybridization and washing conditions were as described (23).

\section{Characterization of sterol 27-hydroxylase mutations in CTX cases of Moroccan origin}

Subjects. Five CTX patients from four unrelated Jewish families (families 201, 203, 204, and 206) of Moroccan extraction were allocated through the main referral center for CTX patients in Israel (Soroka

A

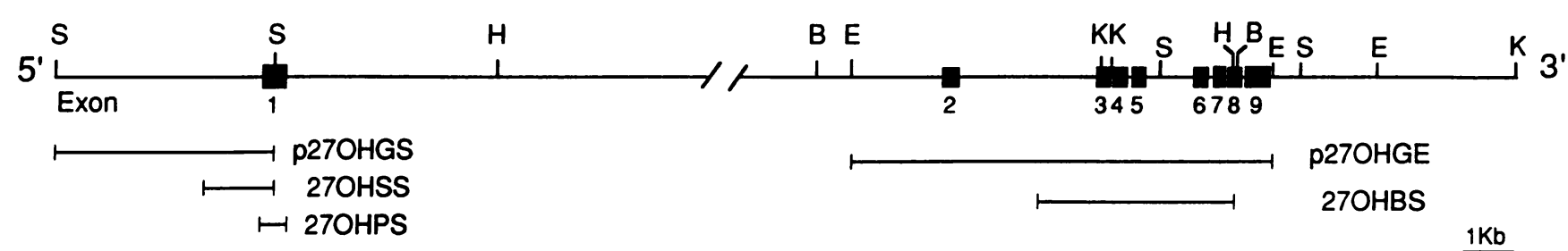

B

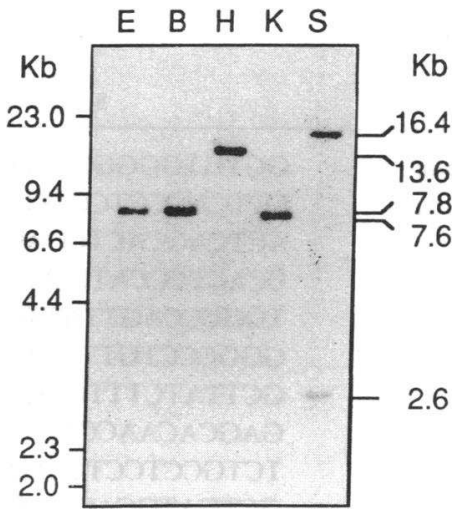

Figure 1. Structure of the human sterol 27-hydroxylase gene. $(A)$ The exon-intron organization of the gene is drawn to scale. Exons are indicated by the numbered boxes and introns by the connecting lines. The positions of cleavage sites for the restriction enzymes EcoRI (E), BamHI (B), HindIII ( $\mathrm{H})$, KpnI (K), and SacI $(S)$ are indicated along the gene schematic. Cloned fragments described under Methods are marked underneath. $(B)$ Southern blot analysis of genomic DNA. $8 \mu \mathrm{g}$ of high molecular weight DNA from human peripheral blood leukocytes were digested with the indicated restriction enzymes and subjected to Southern blotting analysis with a probe derived from the $3^{\prime}$ region of the human sterol 27-hydroxylase cDNA (exons 3-8). The washed filters were exposed to an X-ray film for $4 \mathrm{~d}$ with two intensifying screens. HaelII-digested bacteriophage $\lambda$ DNA size standard is shown on the left while the calculated size of each fragment is shown on the right. 
Medical Center, Beer-Sheba). The diagnosis was verified according to the previously defined clinical and laboratory criteria (1). The phenotypic characteristics and the pedigree structure of three patients that are included in the current study had been previously reported by Berginer and Abeliovich (19). The following identification numbers are used [current study (previous study)]: $201-7$ (B,IV-30), 201-8 (B,IV-31) and 203-3 (C,V-16). The study was approved by the Committee on Research Involving Human Subjects of The Hadassah University Hospital-Hadassah Medical School, Jerusalem.

Biochemical analyses. Plasma total triglyceride, cholesterol, and HDL-cholesterol levels were determined on fasting blood samples using commercially available diagnostic kits (Boehringer Mannheim Gmb H, Mannheim, FRG). Plasma LDL-cholesterol levels were calculated according to the Friedewald-Levy formula (24). Plasma cholestanol levels were determined by the gas chromatographic method $(6,25)$.

RNA and DNA mutation analysis. Skin biopsies were obtained from the CTX patients, fibroblast cultures were established, and total cellular RNA was extracted in $4 \mathrm{M}$ guanidine thiocyanate (26). The RNA was denatured in $3 \mathrm{M}$ glyoxal, subjected to electrophoresis on $1.6 \%$ agarose gel (27) and transferred to a nylon-based membrane (Biotrans) and hybridized with an $\left[\alpha{ }^{32} \mathrm{P}\right] \mathrm{dCTP}$-labeled full-length human sterol 27-hydroxylase cDNA probe (22).

Southern blotting analysis was performed as described above using genomic DNA that had been extracted from blood leukocytes obtained from the CTX patients and probed with an identical probe. To identify the mutations that cause CTX in Jewish patients of Moroccan extraction, we have used PCR amplification (20) of genomic DNA and single-strand conformational polymorphism (SSCP) analysis (28). All exons and the $5^{\prime}$ flanking region of the sterol 27-hydroxylase gene were amplified using the oligonucleotides listed in Table I. The PCR reactions included $10 \mu \mathrm{Ci}$ of $\left[\alpha-{ }^{32} \mathrm{P}\right] \mathrm{dCTP}$ and the conditions were as described above. The PCR products of the 5' region of the gene and exons 6-9 were digested with HaeII and Avall restriction endonucleases, respectively, before analysis on a $6 \%$ nondenaturing polyacrylamide gel containing $10 \%$ ( vol/vol) glycerol. After the identification of abnormally migrating bands, the appropriate exon was PCR-amplified using similar oligonucleotides that include six-nucleotide 5 ' extensions with the consensus sequence for BamHI (upstream oligonucleotides) and SphI (downstream oligonucleotides) restriction endonucleases, respectively, and three additional irrelevant nucleotides (ATA). The PCR products were analyzed on a $1.5 \%$ agarose gel, the appropriate band was extracted, purified and subjected to BamHI/SphI digestion followed by subcloning into bacteriophage M13. Sequence analysis of both strands of two independent M13 clones obtained from two sepa- rate PCR reactions was performed using the dideoxynucleotide chain termination method (29).

Direct detection of the mutant alleles. Direct detection methods were used to confirm the presence of the two mutations in genomic DNA samples from the four index cases. The mutation in exon 4 creates a new BpmI restriction site and deletes a FokI site. Intron 4 mutation does not change a restriction site and therefore we used the PCR-primer-introduced restriction analysis method $(30)$ to create a new StyI site only in the mutant, PCR-amplified allele. The upstream oligonucleotide primer 27OHMM (5'-CTTTCCTCTTCTCTGTTGCTTTCCC $-3^{\prime}$ ) included a single base substitution (underlined) where adenosine was substituted by cytosine, three nucleotides upstream to the beginning of exon 5 . The downstream oligonucleotide primer was identical to the 3 ' oligonucleotide primer used for amplification of exon 5 ( Table I). We applied the SSCP method (as described above) to detect the mutant gene and determine its frequency in 250 unrelated individuals of Jewish Moroccan extraction.

\section{Results}

Structure of the sterol 27-hydroxylase gene. After screening of the human genomic library, four hybridization-positive clones were isolated. The genomic inserts were probed by using ${ }^{32} \mathrm{P}$-labeled oligonucleotides derived from the human sterol 27-hydroxylase cDNA. Three clones hybridized to oligonucleotides derived from the $3^{\prime}$ coding region and the fourth with an upstream oligonucleotide.

The structure of the gene was derived from plasmid mapping and confirmed by Southern blotting analysis of control human genomic DNA (Fig. 1). The gene spans at least $18.6 \mathrm{~kb}$ and includes nine exons and eight introns. The exact locations of the introns were determined by DNA sequencing, and their sizes were verified by the PCR. As no overlapping genomic bacteriophage $\lambda$ clones were found, the minimal size of intron 1 was estimated from Southern blotting of genomic DNA using SacI restriction analysis and hybridization with an exon 1-specific probe (data not shown). The DNA sequences at the intron-exon junctions are shown in Table II and obey the GT/ AG rule of eukaryotic genes (31). As indicated in Fig. 1, the sizes of the DNA fragments generated with five restriction endonucleases agreed with those predicted from the gene map, confirming that the sterol 27 -hydroxylase is a single copy gene. The

Table I. Sequence and Locations of Oligonucleotides in Sterol 27-Hydroxylase Gene That Were Used for PCR-SSCP Analysis

\begin{tabular}{|c|c|c|c|c|}
\hline $\begin{array}{l}\text { Oligonucleotide } \\
\text { target }\end{array}$ & Location & Amplification & Sequence $5^{\prime}$ to $3^{\prime}$ & Position* \\
\hline RL14 & 5'-flanking & 5'-flanking & GGTGTGGGGCTTCCCGATTT & -335 to -315 \\
\hline RL15 & Exon 1 & 5'-flanking & ССTCAGCCTCGCGCAGCCCA & +30 to +10 \\
\hline la & 5'-flanking & Exon 1 & ACTCAGCACTCGACCCAAAGGTGCA & -42 to -17 \\
\hline $1 b$ & Intron 1 & Exon 1 & ССАСТСССАTCCСCAGGACGCGATG & $14^{\ddagger}$ \\
\hline $2 \mathbf{a}$ & Intron 1 & Exon 2 & TGGCCCAGTTATTCAGTTTTGATTG & $10^{\ddagger}$ \\
\hline $2 b$ & Intron 2 & Exon 2 & GGGCCCTGTTCCAGTCCCTTCAGGC & $10^{\ddagger}$ \\
\hline $3 a$ & Intron 2 & Exon 3 & GCTTATCTTTGTGCTGTTCCTCTGC & $9^{\ddagger}$ \\
\hline $3 b$ & Intron 3 & Exon 3 & GAGCACAACCTCTCCСТGACCCATT & $33^{\ddagger}$ \\
\hline $4 a$ & Intron 3 & Exon 4 & TCTGCCTCCTGTGATGGCCTCTGTG & $10^{\ddagger}$ \\
\hline $4 b$ & Intron 4 & Exon 4 & GCTGATGCACAGACCTGGAGTCACC & $39^{\ddagger}$ \\
\hline $5 a$ & Intron 4 & Exon 5 & GCTCTTGGTCCTTGGAGATCATGAC & $40^{\ddagger}$ \\
\hline $5 b$ & Intron 5 & Exon 5 & ACTGGTTACGGTTGGGAGCTGGGGG & $30^{\ddagger}$ \\
\hline $6 a$ & Intron 5 & Exon 6-9 & TTCCTAGAATCGCCTCACCTGATCT & $17^{\ddagger}$ \\
\hline $9 b$ & 3'-untranslated, exon 9 & Exon 6-9 & CCCAGCAAGGCGGAGACTCA & $3^{\S}$ \\
\hline
\end{tabular}

* The A of the ATG initiation codon is number $+1 .{ }^{\ddagger}$ Minimal distance from exon. ${ }^{\S}$ Downstream from the TGA (termination codon). 
Table II. Exon-Intron Organization of the Human Gene Encoding Sterol 27-Hydroxylase

\begin{tabular}{|c|c|c|c|c|c|}
\hline \multirow{2}{*}{$\begin{array}{c}\text { Exon } \\
\text { number }\end{array}$} & \multirow{2}{*}{$\begin{array}{l}\text { Exon } \\
\text { size }\end{array}$} & \multicolumn{3}{|c|}{ Sequence at the exon-intron junction } & \multirow{2}{*}{$\begin{array}{c}\text { Amino } \\
\text { acid } \\
\text { interrupted }\end{array}$} \\
\hline & & $5^{\prime}$ splice donor & & 3 splice acceptor & \\
\hline & $b p$ & & & & \\
\hline 1 & $>255$ & $\begin{array}{l}\text { TTACAGgtaacccgcg } \\
255\end{array}$ & $\ldots 12.20 \mathrm{~kb} \ldots$ & $\begin{array}{r}\text { aactccacagGTGCTT } \\
261\end{array}$ & $G \ln (52)$ \\
\hline 2 & 191 & $\begin{array}{c}\text { CACCACgtgagctggg } \\
446\end{array}$ & $\ldots 2.70 \mathrm{~kb} \ldots$ & $\begin{array}{r}\text { cgtcctgcagGGAAGG } \\
452\end{array}$ & Thr (116) \\
\hline 3 & 200 & $\begin{array}{l}\text { TGGAAGgtaccettgc } \\
646\end{array}$ & $\ldots 0.11 \mathrm{~kb} \ldots$ & $\begin{array}{r}\text { cactactcagCTATTT } \\
652\end{array}$ & Ala (183) \\
\hline 4 & 198 & $\begin{array}{c}\text { CCTTTGgtgaggactc } \\
844\end{array}$ & $\ldots 0.15 \mathrm{~kb} \ldots$ & $\begin{array}{r}\text { gctttcacagGGAAGA } \\
850\end{array}$ & Gly (249) \\
\hline 5 & 174 & $\begin{array}{c}\text { GACACGgtgcgtgaag } \\
1018\end{array}$ & $\ldots 0.96 \mathrm{~kb} \ldots$ & $\begin{array}{r}\text { tatcttctagACATCC } \\
1023\end{array}$ & $\operatorname{Thr}(306)$ \\
\hline 6 & 167 & $\begin{array}{l}\text { TCTGCGgtaggacaga } \\
\quad 1184\end{array}$ & $\ldots 0.24 \mathrm{~kb} \ldots$ & $\begin{array}{r}\text { ttccetgcagTCTCTA } \\
1190\end{array}$ & $\operatorname{Arg}(362)$ \\
\hline 7 & 79 & $\begin{array}{l}\text { AAGAACgtgagtgggc } \\
1263\end{array}$ & $\ldots 0.06 \mathrm{~kb} \ldots$ & $\begin{array}{r}\text { tcctttatagACCCAG } \\
1269\end{array}$ & Asn (388) \\
\hline 8 & 213 & $\begin{array}{c}\text { GCAAGGgtgagctggg } \\
1476\end{array}$ & $\ldots 0.15 \mathrm{~kb} \ldots$ & $\begin{array}{r}\text { taccccccagCTGATC } \\
1482\end{array}$ & $\operatorname{Arg}(459)$ \\
\hline 9 & 344 & $\begin{array}{c}\text { CCTTGGgtcagaatat } \\
1820\end{array}$ & & & \\
\hline
\end{tabular}

Capital letters and numbers refer to exon sequences, with the A of the ATG initiation codon being assigned number 1; small letters refer to intron sequences; amino acids are numbered according to Cali and Russell (17).

sequence encoding the "extrapeptide" mitochondrial signal is located in exon 1 , the putative ferredoxin binding site in the $3^{\prime}$ end of exon 6 , and the predicted heme binding cysteine residue in exon 8 . These sites were determined based on the structure of the cDNA and protein (18).

DNA sequencing of the $5^{\prime}$ flanking region. The DNA sequence of the $5^{\prime}$ untranslated region is shown in Fig. 2. This sequence was derived from two partially overlapping bacteriophage M13 clones (27OHSS and 27OHPS). The sequence includes $500 \mathrm{bp}$, displays a high $\mathrm{G}+\mathrm{C}$ content and possible binding sites for the transcription factor $\mathrm{Spl}$ and the liver transcription factor, LF-B1. A canonical TATA sequence and CAAT box did not appear to be present in the immediate 5'-flanking region.

Clinical manifestations and biochemical analyses. The four Jewish families were traced back to their origin from Morocco. Family 201 emigrated from Taroudant, family 203 from Mogador, family 204 from Marrakech, and family 206 from Sefrou. Consanguinity, at the first cousin level, was demonstrated in all families except for family 204. All five Moroccan patients were females aged 23-47 yr ( Table III). The clinical manifestations appeared during childhood. Although the physical findings were similar, it is striking that patient 201-8 did not have xanthomatosis and patient 206-3 had only mild thickening of the Achilles tendons. Patient 206-3 also differed in the distribution of her neurological manifestations. She had only mild dementia but significant cerebellar dysfunction. The degree of brain atrophy as determined by computerized tomography and magnetic resonance imaging was most striking in the older patients (203-3 and 204-8). Plasma cholestanol levels were elevated in all patients, the highest in patient 203-3 and the lowest in 204-8. Other plasma lipid and lipoprotein levels were normal except for patient 201-7 that had abnormally elevated total cholesterol and LDL cholesterol levels.
$R N A$ and DNA mutation analyses. RNA blotting analysis revealed the absence of sterol 27-hydroxylase mRNA in the CTX samples and Southern blotting analysis showed that the

-500 CCAGGGATCAGATGACTGGCCCCCCTCGCTCCGAACTGACTCCGGGATCA

-450 ATCCGGAGGCCATTGGGAGAAGCCGAGGGCAGCTTAGCCACGGCCGGTT

-400 CCCGTTCCCTCCAGGACGCGAGGGTCGCCTTGGGTGGGGAACCCGCGACC

-350 GGGCGAGGACCTATCCCGGTGTGGGGCTTCCCGATTTCGGAAAGAATCTC

-300 GCTGCACCCCCGCCCAGAGTTCAGACCAAGCGAAAAGTTATTTGAGAGGC

-250 CTCGGGGGCGCGGGTTAGGAGTCGTGGCGGAGGCTTGGTCGGGGCGCCG

-200 TGGATATCCCCGAGTCACCGCGTCCCTCTCCTGCAGCTCCCGCGTCGCTG

-150 GGAGGAGCGAGGGAGCGAGCGGGAAGGGTCTAGCTGGCCTTTGCTCGGC

-100 CCTCCCCAGCGCCCGGCTTTGAACCCGCCCTGCACTGCTGTCTGGGCGGG

-050 TCCGgGGACTCAGCACTCGACCCAAAGGTGCAGGCGCGCGAGCACAACCC

MetAlaAlaLeuglycysalaArgLeuArgTrpAlaLeuArgGly +001 ATGGCTGCGCTGGGCTGCGCGAGGCTGAGGTGGGCGCTGCGAGGG. .

Figure 2. DNA sequence analysis of the 5'-flanking region of the human sterol 27-hydroxylase gene. The nucleotide sequence of the 5'flanking region of the gene is shown. The sequence is numbered on the left with negative numbers assigned to the 5'-flanking nucleotides. A consensus CCGCCC or GGGCGG present in the recognition sequence for the transcription factor $\mathrm{Sp} 1$ are overlined as are GTTATT, the nucleotides present in the recognition sequence for liver transcription factor LF-B1. 
Table III. Molecular Identification and Clinical and Laboratory Manifestations of the CTX Patients before Treatment

\begin{tabular}{|c|c|c|c|c|c|}
\hline Patient number & $201-7$ & $201-8$ & 203-3 & 204-8 & 206-3 \\
\hline $\begin{array}{l}\text { Sterol } 27 \text {-hydroxylase } \\
\text { mutation }\end{array}$ & $\begin{array}{l}\text { Splice junction } \\
\quad \text { (homozygote) }\end{array}$ & $\begin{array}{l}\text { Splice junction } \\
\text { (homozygote) }\end{array}$ & $\begin{array}{l}\text { Frameshift } \\
\text { (homozygote) }\end{array}$ & $\begin{array}{l}\text { Splice junction and } \\
\text { frameshift (compound } \\
\text { heterozygote) }\end{array}$ & $\begin{array}{l}\text { Frameshift } \\
\text { (homozygote) }\end{array}$ \\
\hline \multicolumn{6}{|l|}{ Background data } \\
\hline Sex & $\mathrm{F}$ & $\mathrm{F}$ & $\mathrm{F}$ & $\mathrm{F}$ & $\mathrm{F}$ \\
\hline Age $(y r)$ & 27 & 25 & 47 & 34 & 23 \\
\hline Age of onset $(y r)$ & 4 or earlier & 3 or earlier & early childhood & late childhood & $8-9$ \\
\hline Consanguinity & + & + & + & - & + \\
\hline \multicolumn{6}{|l|}{ Physical findings } \\
\hline Myopathic facial expression & +++ & +++ & +++ & + & + \\
\hline Pes cavus & ++ & ++ & ++ & ++ & ++ \\
\hline Tendon xanthomata & +++ & - & ++++ & ++ & + \\
\hline Cataracts & ++++ & ++++ & ++++ & ++++ & ++++ \\
\hline Dementia & +++ & +++ & ++++ & ++ & + \\
\hline Pyramidal signs & ++ & ++ & ++ & + & ++ \\
\hline Cerebellar signs & + & + & ++ & + & +++ \\
\hline Sensory loss & - & + & + & - & - \\
\hline Convulsions & febrile up to $11 \mathrm{yr}$ & febrile up to $5 \mathrm{yr}$ & + & - & $\begin{array}{l}\text { grand mal attack } \\
\text { at age } 20\end{array}$ \\
\hline \multicolumn{6}{|l|}{ Neurological studies } \\
\hline EEG abnormality* & +++ & +++ & +++ & +++ & +++ \\
\hline Diffuse brain atrophy ${ }^{\ddagger}$ & + & + & +++ & ++ & + \\
\hline $\begin{array}{l}\text { Plasma lipids and lipoproteins } \\
\text { Cholesterol, mmol/liter } \\
(m g / d l)\end{array}$ & $7.1(276)$ & $3.4(131)$ & $4.9(189)$ & $4.9(190)$ & $4.4(173)$ \\
\hline $\begin{array}{l}\text { Cholestanol, } \mathrm{mmol} / \text { liter } \\
(\mathrm{mg} / \mathrm{dl})^{\S}\end{array}$ & $0.19(7.3)$ & $0.14(5.4)$ & $0.23(9.0)$ & $0.06(2.2)$ & $0.07(2.6)$ \\
\hline $\begin{array}{l}\text { Triglyceride, } \mathrm{mmol} / \text { liter } \\
\quad(\mathrm{mg} / \mathrm{dl})\end{array}$ & $2.0(180)$ & $0.5(43)$ & $1.8(159)$ & $1.0(86)$ & $1.1(98)$ \\
\hline $\begin{array}{l}\text { HDL-cholesterol, } \mathrm{mmol} / \\
\text { liter }(\mathrm{mg} / \mathrm{dl})\end{array}$ & $1.8(70)$ & $1.8(70)$ & $1.3(50)$ & $1.3(52)$ & $1.8(70)$ \\
\hline $\begin{array}{l}\text { LDL-cholesterol, } \mathrm{mmol} / \\
\qquad \text { liter }(\mathrm{mg} / \mathrm{dl})^{\|}\end{array}$ & $4.4(170)$ & $1.3(52)$ & $2.7(107)$ & $3.1(121)$ & $2.1(83)$ \\
\hline
\end{tabular}

Scoring system: $(++++)$ to $(-)=$ very severe to absent. ${ }^{*}$ Irregular diffuse slow activity with periodical sharp waves discharges. ${ }^{\ddagger}$ Confirmed by magnetic resonance imaging and computerized tomography. ${ }^{8}$ normal level $<0.03 \mathrm{mmol} / \mathrm{liter}(1 \mathrm{mg} / \mathrm{dl})$. "Calculated according to Friedewald et al. (24).

size of the BamHI restriction fragments was identical for all genomic DNA samples that were analyzed (Fig. 3). It was thus concluded that the absence of mRNA in the Moroccan CTX patients does not result from a major gene rearrangement. SSCP analysis of the $5^{\prime}$ region of the gene and all exons and flanking sequences was performed. Abnormally migrating bands were found only in the analysis of exons 4 and 5 (Fig. 4). SSCP analysis of exon 4 showed that patients 203-3 and 206-3 had a different band pattern while patient 201-7 had identical band pattern as compared to the control. Patient 204-8 showed both band patterns. Analysis of exon 5 revealed that patient 201-7 had an abnormal band pattern, patients 203-3 and 206-3 were identical to the control and again patient 204-8 had both band patterns. The SSCP analysis suggested therefore that patients 203-3 and 206-3 are homozygous for a mutation in exon 4 , patient 201-7 is homozygous for a mutation in exon 5, and patient $204-8$ is a compound heterozygote harboring both mutations.

Sequence analysis revealed that the mutation in exon 4 is a deletion of thymidine that results in a frameshift and in prema- ture termination codon 35 nucleotides downstream, the second mutation, a null mutation, is a guanosine to adenosine substitution at the $3^{\prime}$ splice acceptor site of intron 4 (Fig. 5). PCR and restriction analysis were then used for the analysis of the five CTX cases that participated in the study. BpmI restriction analysis confirmed that CTX cases 203-3 and 206-3 were homozygote and 204-8 heterozygote for the frameshift mutation. By using PCR-primer-induced restriction analysis and StyI restriction analysis it was confirmed that CTX cases 201-7 and 201-8 were homozygote and 204-8 heterozygote for the splice junction mutation (data not shown).

DNA samples from 250 unrelated individuals of Jewish Moroccan origin were screened to determine the heterozygote frequency of the two mutations. The sample includes $457 \mathrm{pa}-$ rental Moroccan alleles (43 individuals had one parent that originated from another country), revealed that one carries exon 4 and two carry intron 4 mutations. Both parents of each one of the three heterozygotes originated from Morocco. The point estimate of the Moroccan mutations allele frequency is therefore 0.00658 ( $95 \%$ confidence interval $0.000-0.013$ ). The 


\section{CTX

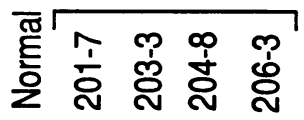

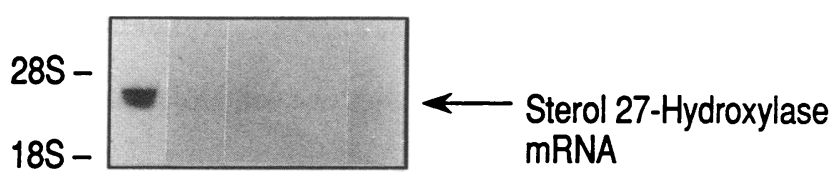
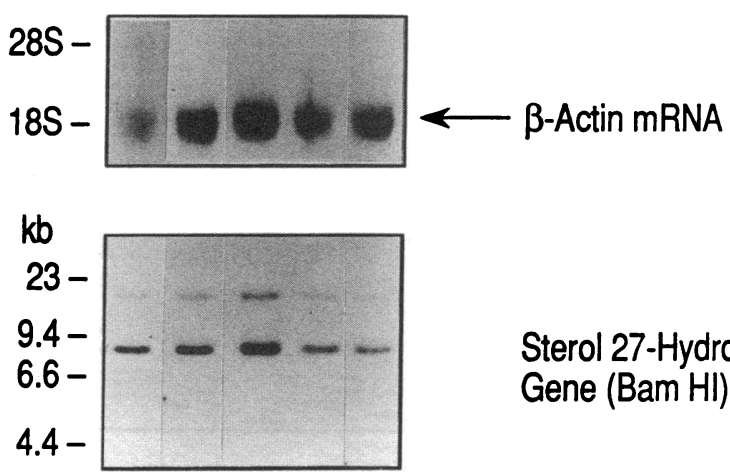

Sterol 27-Hydroxylase Gene (Bam HI)

Figure 3. Blot hybridization of CTX fibroblast RNA and DNA. Total cellular RNA was prepared from fibroblast cultures and genomic DNA from blood leukocytes. RNA and Southern blotting analysis were performed and the nylon membranes were probed with a fulllength ${ }^{32} \mathrm{P}$-labeled human sterol 27 -hydroxylase $\mathrm{cDNA}$ probe. For comparative analysis, the RNA blot was also probed with a $\beta$-actin cDNA probe.

estimate for homozygosity is therefore 0.0000433 . Inasmuch as the current Jewish population that originated from Morocco in Israel is 498,000 (32) and the degree of interethnic mixture (calculated from our sample) is only $8.6 \%$, it suggests that 20
CTX cases $(0.0000433 \times 498,000 \times 0.914)$ that result from the two mutant alleles in nonconsanguineous marriages may exist. So far, only two nonconsanguineous Jewish Moroccan CTX families are known: family 204 and another family which is not included in this study (Berginer, unpublished observation).

\section{Discussion}

Here we show that in Moroccan Jews, CTX is caused by two distinct sterol 27-hydroxylase gene mutations. These two mutations, a deletion of thymidine in exon 4 and a guanosine to adenosine substitution at the $3^{\prime}$ splice acceptor site of intron 4 , in addition to an estimate of carrier frequency, provide an indication of the expected prevalence of CTX in the Israeli Jewish Moroccan community.

Moroccan Jews have been socially isolated from non-Jews in Morocco and it has been established that they resemble other Jewish populations with regard to several polymorphic genetic systems (33). The possibility of the existence of a founder mutation in the Jewish Moroccan population is related to the unique demographic characteristics of this ethnic group. Some of its ancestors immigrated to Morocco before the destruction of the Second Temple (34) where they intermarried with the Berber tribes $(35,36)$. After the Arab conquest of Morocco in the 8th century the Jews lived in ghettos where inbreeding was common (37). This population was diluted with a massive Jewish refugee immigration from the Iberian peninsula at the end of the 15 th century. This Moroccan Jewish community then migrated almost exclusively to Israel.

The fact that two mutations are prevalent in this community is also compatible with a founder mechanism as has recently been shown for familial hypercholesterolemia in Afrikaners (38) and in the Finnish population (39). Based on the screening results of 250 unrelated individuals for carrier fre-

\section{EXON 4}
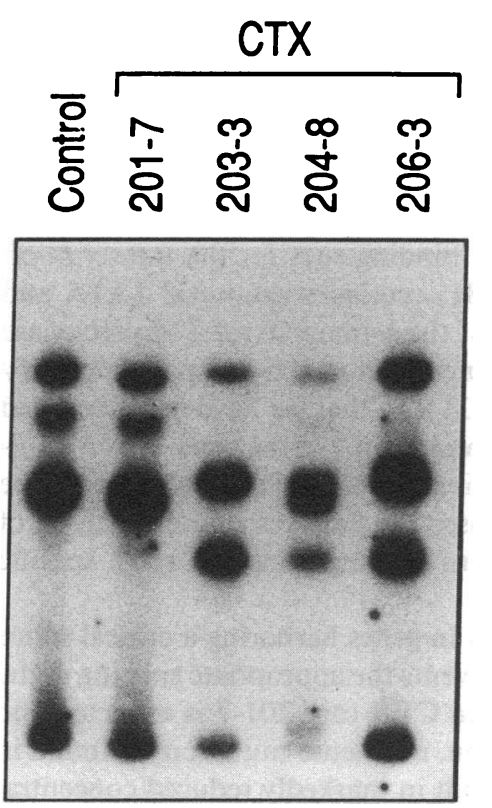

$-\quad-\quad+\quad+$

$-\quad+-+$
EXON 5
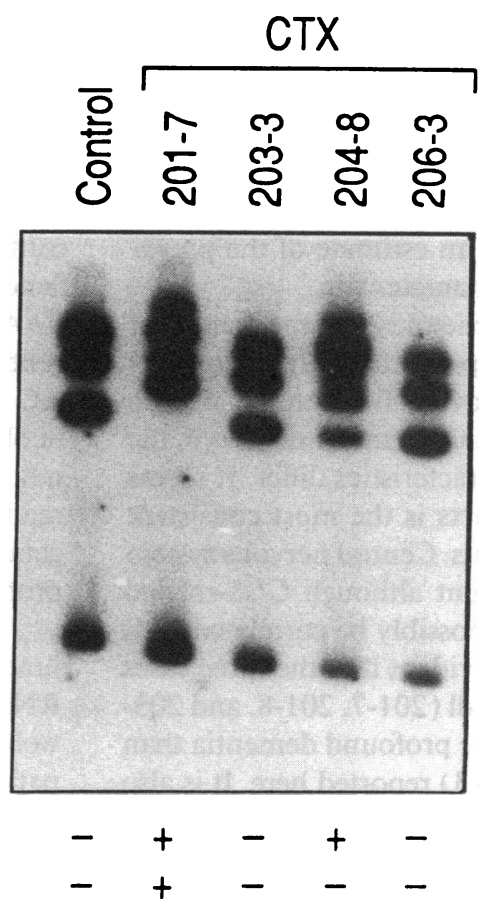

Figure 4. SSCP analysis of genomic DNA. Exon 4 of the sterol 27-hydroxylase gene was amplified using oligonucleotide EXINT45 (5'CTATTTGCTACATCCTGTTCGAGAA-3') that is homologous to the first 25 bases of exon 4 and oligonucleotide $4 \mathrm{~b}$ (Table I). Exon 5 was amplified using oligonucleotides $5 \mathrm{a}$ and $5 \mathrm{~b}$ ( Table I). After amplification, the PCR products were heat denaturated and subjected to electrophoresis on a $6 \%$ nondenaturing polyacrylamide gel containing $10 \%$ glycerol followed by autoradiography for $24 \mathrm{~h}$. For the determination of the possible genotypes, the band pattern obtained for the control DNA was designated: - - (two normal alleles), for the cases that showed a completely different band pattern and therefore may be homozygote for a mutation; ++ (two mutant alleles); and +- (heterozygote), for a case with both band patterns. 
Exon 4 Intron $4 \quad$ Exon 5

Amino Acid No.:

Amino Acid: .. TyrLeuAspGlyTrPAsnAlaIlePheSerPheG................... lyLysLys...

Nucleotide:

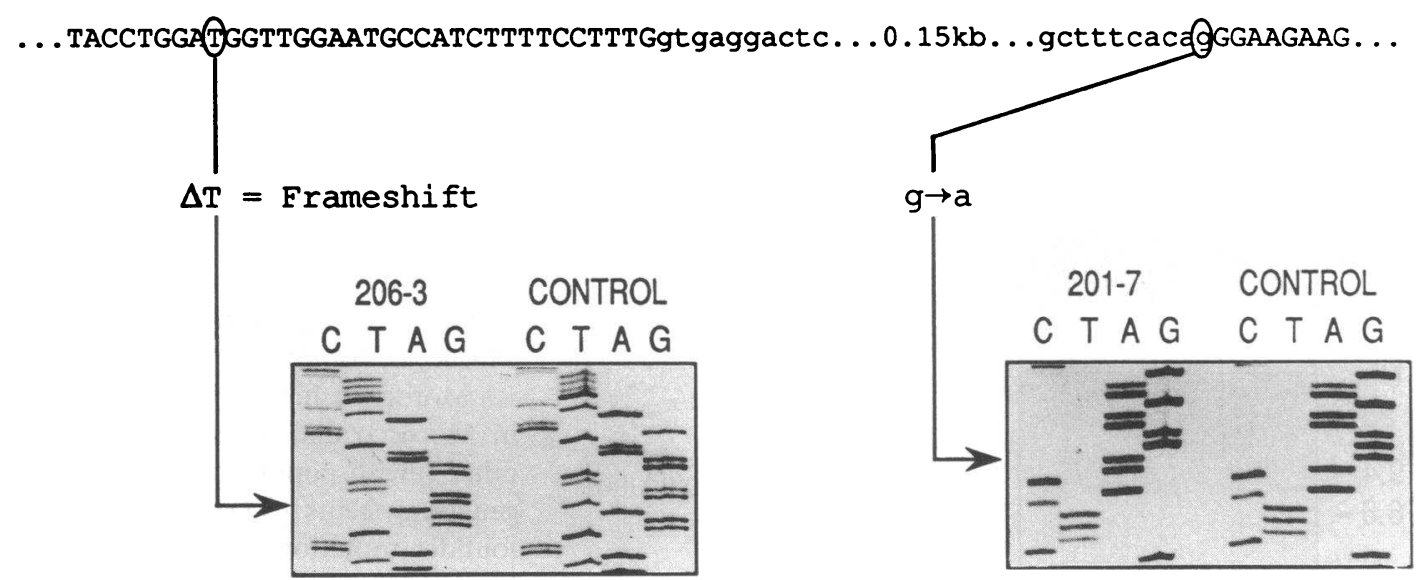

Figure 5. DNA sequence analysis of the mutant gene in CTX cases 206-3 and 201-7. Exons 4 and 5 and their flanking sequences were PCRamplified using genomic DNA from CTX cases 206-3 and 201-7, respectively. Control DNA samples were included for comparison. Sequence analysis was performed on cloned DNA (see Methods). The normal sequence is shown and the exact location and nature of both mutations indicated. Upper-case letters indicate exon sequences and lower-case letters intron sequences. The sequences shown are of the coding strands of both mutant alleles.

quency of the two mutations, we predict the existence of 20 CTX cases that result from random matings in Jews of Moroccan origin in Israel. Inasmuch as only two nonconsanguineous families with CTX from this community are known, it is expected that additional families will be identified in the near future.

CTX is a rare autosomal recessive disease that does not interfere with fertility (40). Its increased prevalence in Moroccan Jews may result primarily from an exceedingly high rate of consanguinity. In Moroccan Jews, cousin marriage is traditionally acceptable, a fact which appears to be shown in Jews and Moslems (41). The high consanguinity rate of $10.7 \%$ reported three decades ago (42) may also explain the increased frequency of several other distinct recessive genetic diseases including steroid $11 \beta$-hydroxylase deficiency (43), complement deficiency (44), and Tay-Sachs disease (45). The present consanguinity rate in the Moroccan Jewish community is unknown and thus does not allow for an estimate of the prevalence of CTX based on this social characteristic.

Analysis of the clinical and biochemical characteristics of five CTX cases of Moroccan origin presented here ( Table III) reveals that, although all five cases have null mutations that do not produce any detectable $\mathrm{mRNA}$ and therefore no enzymatic activity is expected, the clinical characteristics differ. It seems as though the appearance of cataracts is the most consistent characteristic of CTX in these patients. Central nervous system (CNS) involvement is always present although CNS-related clinical signs may differ and could possibly be correlated with the plasma cholestanol levels. It is evident that the three cases with plasma cholestanol of $>5 \mathrm{mg} / \mathrm{dl}$ (201-7, 201-8, and 2033 ) at the time of diagnosis have more profound dementia than the other two cases (204-8 and 206-3) reported here. It is also evident that the degree of dementia does not necessarily correlate with the degree of brain atrophy as demonstrated by magnetic resonance imaging and computerized tomographic scan- ning. These observations suggest that the mechanism for the development of dementia in CTX is complex and may be related at least in part to the toxic effect of bile alcohols.

The absence of tendon xanthomas in patient 201-8 is striking especially when compared to her sister (201-7) and may be related to her very low LDL-cholesterol levels. Low LDL-cholesterol levels are commonly found in CTX and could possibly be related to overexpression of LDL receptors (46). In some cases LDL-cholesterol levels are elevated as in patient 201-7 where the markedly increased plasma LDL-cholesterol concentration could contribute to the development of severe tendon xanthomas in this relatively young patient.

The current investigation reveals the structure of the human sterol 27-hydroxylase gene that spans at least $18.6 \mathrm{~kb}$ of genomic DNA. The gene includes nine exons and eight introns. The 500-bp sequence immediately upstream of the translation initiation codon has a high guanosine and cytosine content, contains potential binding sites for the transcription factors, Spl (47) and LF-B1, and lacks canonical TATA and CAAT boxes. The exons of the human sterol 27-hydroxylase gene are bounded by sequences that match the splice sites GT/ AG consensus sequences ( 31 ). In that we have not succeeded in obtaining clones that span intron 1 of the gene, only a minimal estimate for the size of intron 1 and of the gene itself can be made. This estimate is based on SacI restriction analysis of genomic DNA and Southern blotting using an exon 1 specific probe.

The absence of mRNA in genes harboring a critical splice junction mutation that prevents the appropriate splicing of the RNA precursor as found in CTX case 201-7 is expected and well understood. In addition, non-sense mutations as found in patient 206-3 may also result in markedly reduced concentrations of mRNA. Although the molecular mechanisms leading to this phenomenon are not well understood, several possibilities have been suggested (48-50). 
The gene for the sterol 27-hydroxylase ( $C Y P 27)$ belongs to a group of now over 150 cytochrome P450 genes (51). The sterol 27-hydroxylase gene that includes nine exons, is similar in structure to $C Y P 11 B 1$ and $C Y P 11 B 2$ genes encoding the human steroid $11 \beta$-hydroxylase (52). To date, cytochrome P450 genes have been classified into 27 families, each defined as unique when having $<40 \%$ resemblance to members of other families. All genes within a given family are predicted to have the same number of exons and similar exon/intron boundaries (53), suggesting that the rabbit 27-hydroxylase (54) and the rat 27 -hydroxylase $(55,56)$ genes will be similar in structure to the human gene.

The enzyme sterol 27-hydroxylase belongs to the mitochondrial P450s which require ferredoxin as a co-factor and ferredoxin reductase for electron transfer. Several conserved domains have been recognized in the $\mathrm{P} 450$ mitochondrial proteins, suggesting that the organization of the exons might correlate with functional domains of the protein. We found that the sequence encoding the hydrophobic "extrapeptide" mitochondrial signal is located in exon 1 and that the predicted hemebinding cysteine residue resides in exon 8 of the gene. The putative ferredoxin binding site (57) is located at the $3^{\prime}$ end of exon 6 . Three potential binding sites for the transcription factor SP1 and one for the liver transcription factor LF-B1 were also identified. This is significant as the expression of the sterol 27-hydroxylase gene in the liver appears to be independent of regulation by cholesterol $(17,54)$. SP1 has been widely described as playing a role in the expression of "house-keeping" genes (58), while the liver transcription factor LF-B1 is required for the expression of liver specific genes. The importance of these sites for the transcriptional control of the human sterol 27-hydroxylase remains to be elucidated.

Elucidation of the sterol 27-hydroxylase gene structure and analysis of mutant alleles that underlie CTX may provide the basis for future research in several important directions. These directions include the analysis of the regulatory mechanisms of sterol 27-hydroxylase gene expression, the molecular diagnosis of CTX at the pre-symptomatic stage, and the study of pathogenetic mechanisms that lead to the major manifestations of the disease in molecularly defined CTX cases. These studies are currently underway in our laboratory.

\section{Acknowledgments}

We thank Dr. D. W. Russell (Department of Molecular Genetics, University of Texas Southwestern Medical Center at Dallas, TX) for most helpful discussions and for providing the human sterol 27-hydroxylase cDNA clones and other DNA probes used in these experiments, Dr. G. Salen (University of Medicine and Dentistry, New Jersey Medical School, Newark, NJ) for the analysis of plasma cholestanol levels in the study patients, and Dr. H. Giladi and Ms. M. Ben-Naim for their valuable technical assistance.

This research was supported by grant no. 88-0186 from the United States-Israel Binational Science Foundation (BSF), Jerusalem, Israel, and by the Sarah Mayer Research Foundation.

\section{References}

1. Björkem, I., and S. Skrede. 1989. Cerebrotendinous xanthomatosis and phytosterolemia. In The Metabolic Basis of Inherited Disease C. R. Scriver, A. L. Beaudet, W. S. Sly, and D. Valle, editors. McGraw-Hill, Inc., New York. 12831293.

2. Berginer, V. M., G. Salen, and S. Shefer. 1992. Cerebrotendinous xanthomatosis. In Molecular and Genetic Basis of Neurological Disease. R. Rosenberg, S. B. Prusiner, S. DiMauro, R. Bachi, and L. Kunkel, editors. Butterworth Publishers, Stoneham, MA.
3. Berginer, V. M., S. Shany, D. Alkalay, J. Berginer, S. Dekel, G. Salen, G. S. Tint, and D. Gazit. 1992. Osteoporosis, bone fractures and low vitamin D in cerebrotendinous xanthomatosis. Metab. Clin. Exp. 42:69-74.

4. Fujiyama, J., M. Kuriyama, S. Arima, Y. Shibata, K. Nagata, S. Takenaga, H. Tanaka, and M. Osame. 1991. Atherogenic risk factors in cerebrotendinous xanthomatosis. Clin. Chim. Acta. 200:1-11.

5. Menkes, J. H., J. R. Schimschock, and P. D. Swanson. 1968. Cerebrotendinous xanthomatosis: the storage of cholestanol within the nervous system. Arch. Neurol. 19:47-53.

6. Salen, G. 1971. Cholestanol deposition in cerebrotendinous xanthomatosis: a possible mechanism. Ann. Intern. Med. 75:843-851.

7. Salen, G., S. Shefer, and V. M. Berginer. 1991. Biochemical abnormalities in cerebrotendinous xanthomatosis. Dev. Neurosci. 13:363-370.

8. Berginer, V. M., G. Salen, and S. Shefer. 1984. Long-term treatment of cerebrotendinous xanthomatosis with chenodeoxycholic acid. $N$. Engl. J. Med. 311:1649-1652.

9. Nakamura, T., Y. Matsuzawa, K. Takemura, M. Kubo, H. Miki, and S. Tarui. 1991. Combined treatment with chenodeoxycholic acid and pravastatin improves plasma cholestanol levels associated with marked regression of tendon xanthomas in cerebrotendinous xanthomatosis. Metab. Clin. Exp. 40:741-746.

10. Salen, G., S. Shefer, F. W. Cheng, B. Dayal, A. K. Batta, and G. S. Tint. 1979. Cholic acid biosynthesis: the enzymatic defect in cerebrotendinous xanthomatosis. J. Clin. Invest. 63:38-44.

11. Oftebro, H., I. Björkem, S. Skrede, H. Schreiner, and J. I. Pedersen. 1980. Cerebrotendinous xanthomatosis, a defect in mitochondrial 26-hydroxylation required for normal biosynthesis of cholic acid. J. Clin. Invest. 65:1418-1430.

12. Skrede, S., I. Björkem, E. A. Kvittingen, M. S. Buchmann, S. O. Lio, C. East, and S. Grundy. 1986. Demonstration of 26-hydroxylation of $C_{27}$-steroids in human skin fibroblasts and a deficiency of this activity in cerebrotendinous xanthomatosis. J. Clin. Invest. 78:729-735.

13. Björkem, I. 1985. Mechanism of bile acid biosynthesis in mammalian liver. In Sterols and Bile Acids. H. Danielsson and J. Sjövall, editors. Elsvier Science Publishers B. V., Amsterdam. 231-278.

14. Wikvall, K. 1984. Hydroxylations in biosynthesis of bile acids: isolation of a cytochrome $\mathrm{P}-450$ from rabbit liver mitochondria catalyzing 26-hydroxylation of $\mathrm{C}_{2 r}$-steroids. J. Biol. Chem. 259:3800-3804.

15. Okuda, K., O. Masumoto, and Y. Ohyama. 1988. Purification and characterization of $5 \beta$-cholestane- $3 \alpha, 7 \alpha, 12 \alpha$-triol 27 -hydroxylase from female rat liver mitochondria. J. Biol. Chem. 263:18138-18142.

16. Dahlbäck, H., and K. Wikvall. 1988. 25-Hydroxylation of vitamin $D_{3}$ by a cytochrome P450 from rabbit liver mitochondria. Biochem. J. 252:207-213.

17. Cali, J. J., and D. W. Russell. 1991. Characterization of the human sterol 27-hydroxylase: a mitochondrial P-450 that catalyzes multiple oxidation reactions in bile acid biosynthesis. J. Biol. Chem. 266:7774-7778.

18. Cali, J. J., C.-L. Hsieh, U. Francke, and D. W. Russell. 1991. Mutations in the bile acid biosynthetic enzyme sterol 27-hydroxylase underlie cerebrotendinous xanthomatosis. J. Biol. Chem. 266:7779-7783.

19. Berginer, V. M., and D. Abeliovich. 1981. Genetics of cerebrotendinous xanthomatosis (CTX): an autosomal recessive trait with high gene frequency in Sephardim of Moroccan origin. Am. J. Med. Genet. 10:151-157.

20. Saiki, R. K., D. H. Gelfand, S. Stoffel, S. J. Scharf, R. Higuchi, G. T. Horn, K. B. Mullis, and H. A. Erlich. 1988. Primer directed enzymatic amplification of DNA with a thermostable DNA polymerase. Science (Wash. DC). 239:487-491.

21. Hobbs, H. H., M. S. Brown, J. L. Goldstein, and D. W. Russell. 1986 Deletion of exon encoding cysteine-rich repeat of LDL receptor alters its binding specificity in a subject with familial hypercholesterolemia. J. Biol. Chem. 261:13114-13120.

22. Church, G. M., and W. Gilbert. 1984. Genomic sequencing. Proc. Natl. Acad. Sci. USA. 81:1991-1995.

23. Leitersdorf, E., A. Chakravarti, and H. H. Hobbs. 1989. Polymorphic DNA haplotypes at the LDL receptor locus. Am. J. Hum. Genet. 44:409-421.

24. Friedewald, W. T., R. I. Levy, and D. S. Fredrickson. 1972. Estimation of the concentration of low density lipoprotein cholesterol in plasma without use of the preparative ultracentrifuge. Clin. Chem. 18:499-502.

25. Ishikawa, T. T., J. B. Brazier, L. E. Stewart, R. W. Fallot, and C. J. Glueck. 1976. Direct quantitation of cholestanol in plasma by gas liquid chromatography. J. Lab. Clin. Med. 87:345-353.

26. Chirgwin, M. J., E. A. Przybyla, J. R. MacDonald, and J. W. Rutter. 1979. Isolation of biologically active ribonucleic acid from sources enriched in ribonuclease. Biochemistry. 18:5294-5299.

27. McMaster, K. G., and G. G. Carmichael. 1977. Analysis of single- and double-stranded nucleic acids on polyacrylamide and agarose gels by using glyoxal and acridine orange. Proc. Natl. Acad. Sci. USA. 74:4835-4838.

28. Orita, M., Y. Suzuki, T. Sekiya, and K. Hayashi. 1989. Rapid and sensitive detection of point mutations and DNA polymorphisms using the polymerase chain reaction. Genomics. 5:874-879.

29. Sanger, F., S. Nicklen, and A. R. Coulson. 1977. DNA sequencing with chain-terminating inhibitors. Proc. Natl. Acad. Sci. USA. 74:5463-5467.

30. Jacobson, D. R. 1992. A specific test for transthyretin 122 ( Val $\rightarrow$ Ile), based on PCR-primer-introduced restriction analysis (PCR-PIRA): confirmation of the gene frequency in blacks. Am. J. Hum. Genet. 50:195-198. 
31. Mount, S. M. 1982. A catalogue of splice junction sequences. Nucleic Acids Res. 10:459-472.

32. Statistical Abstract of Israel. 1991. Jews by country of origin, place of birth and age. Central Bureau of Statistics. Jerusalem, Israel. 42:90-91.

33. Livshits, G., R. R. Sokal, and E. Kobyliansky. 1991. Genetic affinities of Jewish populations. Am. J. Hum. Genet. 49:131-146.

34. Encyclopedia Judaica. 1978. Morocco. Keter Publishing House, Jerusalem. 326-348.

35. Wilner, D., and M. Kohls. 1962. Jews in high Atlas mountains of Morocco: a partial reconstruction. Jew. J. Sociol. 4:207-241.

36. Simon, M. 1962. Judaisme berbere en Afrique ancienne. In Recherches D'histoire Judeo-Chretienne. Mouton, Paris-La Haye. 30-87.

37. Zafrani, H. 1983. Mille Ans de Vie Juive au Maroc: Histoire et Culture, Religion et Magie. G. P. Masonneuve \& Larose, Paris.

38. Leitersdorf, E., D. R. van Der Westhuyzen, G. A. Coetzee, and H. H. Hobbs. 1989. Two common low density lipoprotein gene mutations cause familial hypercholesterolemia in Afrikaners. J. Clin. Invest. 84:954-961.

39. Koivisto, U. M., H. Turtola, K. Aalto-Setälä, B. Top, R. R. Frants, P. T. Kovanen, A. C. Syvänen, and K. Kuntula. 1992. The familial hypercholesterolemia (FH)-North Karelia mutation of low density lipoprotein receptor gene deletes seven nucleotides of exon 6 and is a common cause of FH in Finland. $J$. Clin. Invest. 90:219-228.

40. Berginer, V. M., R. Carmi, and G. Salen. 1988. Pregnancy in women with cerebrotendinous xanthomatosis (CTX): high risk condition for fetus and newborn infant? Am. J. Med. Genet. 31:11-16.

41. Goldschmidt, E., A. Ronen, and I. Ronen. 1960. Changing marriage systems in the Jewish communities of Israel. Ann. Hum. Genet. 24:191-204.

42. Goldschmidt, E., and T. Cohen. 1964. Inter-ethnic mixture among the communities in Israel. Cold Spring Harbor Symp. Quant. Biol. 29:115-120.

43. White, P. C., J. Dupont, M. I. New, E. Leiberman, Z. Hochberg, and A. Rösler. 1991. A mutation in CYP1 1B1 (Arg-448 $\rightarrow$ His) associated with steroid $11 \beta$-hydroxylase deficiency in Jews of Moroccan origin. J. Clin. Invest. 87:16641667

44. Zimran, A., B. Rudensky, M. R. Kramer, F. Tedesco, M. Ehrenfeld, R. Raz, Z. Greif, M. Gelber, M. Lishner, E. Golan, et al. 1987. Hereditary complement deficiency in survivors of meningococcal disease: high prevalence of $\mathrm{C} 7 / \mathrm{C} 8$ deficiency in Sephardic Jews. $Q$. J. Med. 63:349-358.

45. Drucker, L., R. L. Proia, and R. Navon. 1992. Identification and rapid detection of three Tay-Sachs mutations in the Moroccan Jewish population. Am. J. Hum. Genet. 51:371-377.
46. Ballantyne, C. M., G. L. Vega, C. East, G. Richards, and S. M. Grundy. 1987. Low density lipoprotein metabolism in cerebrotendinous xanthomatosis. Metab. Clin. Exp. 36:270-276.

47. Mitchell, P. J., and R. Tjian. 1989. Transcriptional regulation in mammalian cells by sequence-specific DNA binding proteins. Science (Wash. DC) 245:371-378.

48. Goldfarb, D., and N. Michaud. 1991. Pathways for the nuclear transport of proteins and RNAs. Trends Cell. Biol. 1:20-24.

49. Trecartin R. F., S. A. Liebhaber, J. C. Chang, K. Y. Lee, Y. W. Kan, M Furbetta, A. Angius, and A. Chao. 1981. $\beta^{\circ}$-Thalassemia in Sardinia caused by nonsense mutation. J. Clin. Invest. 68:1012-1017.

50. Urlaub, G., P. J. Mitchell, C. J. Ciudad, and L. A. Chasin. 1989. Nonsense mutations in the dihydrofolate reductase gene affect RNA processing. Mol. Cell. Biol. 9:2868-2880.

51. Nebert, D. W., D. R. Nelson, M. J. Coon, R. W. Estabrook, R. Feyereisen, Y. Fujii-Kuriyama, F. J. Gonzales, F. P. Guengerich, I. C. Gunsalus, E. F. Johnson, et al. 1991. The P450 superfamily: update on new sequences, gene mapping, and recommended nomenclature. DNA Cell Biol. 10:1-14.

52. Mornet, E., Dupont, J., Vitek, A., and P. C. White. 1989. Characterization of two genes encoding human steroid $11 \beta$-hydroxylase $\left(\mathrm{P}-450_{11 \beta}\right)$. J. Biol. Chem. 264:20961-20967.

53. Gonzalez, F. J. 1989. The molecular biology of cytochrome P450s. Pharmacol. Rev. 40:243-288.

54. Andersson, S., D. L. Davis, H. Dahlbäck, H. Jörnvall, and D. W. Russell 1989. Cloning, structure, and expression of the mitochondrial cytochrome P-450 sterol 26-hydroxylase, a bile acid biosynthetic enzyme. J. Biol. Chem. 264:82228229 .

55. Usui, E., M. Noshiro, and K. Okuda. 1990. Molecular cloning of cDNA for vitamin $\mathrm{D}_{3}$ 25-hydroxylase from rat liver mitochondria. FEBS Lett. 262:135138.

56. Su, P., H. Rennert, R. M. Shayiq, R. Yamamoto, Y.-M. Zheng, S. Addya, J. F. Strauss III, and N. C. Avadhani. 1990. A cDNA encoding a rat mitochondrial cytochrome $\mathrm{P}-450$ catalyzing both the 26-hydroxylation of cholesterol and 25-hydroxylation of vitamin $\mathrm{D}_{3}$ : gonadotropic regulation of the cognate mRNA in rat ovaries. DNA Cell Biol. 9:657-665.

57. Tuls, J., L. Geren, and F. Millet. 1989. Fluorescein isothiocyanate specifcally modifies Lysine 338 of cytochrome P450scc and inhibits adrenodoxin binding. J. Biol. Chem. 264:16421-16425.

58. Lewin, B. 1990. Building the transcription complex. In Gene IV. B Lewin, editor. Oxford University Press, Oxford. 543-577. 